\title{
Impact of Particle-Size Reduction on the Solubility and Antidiabetic Activity of Extracts of Leaves of Vinca rosea
}

\author{
Partikül Büyüklüğünün Azaltılmasının Vinca rosea Yaprak Ekstresinin \\ Çözünürlüğü ve Antidiyabetik Aktivitesi Üzerine Etkisi
}

(D) Khalid HUSSAIN*, (D) Abida QAMAR, (D) Nadeem Irfan BUKHARI, (D) Amjad HUSSAIN, (D) Naureen SHEHZADI, (D) Shaista QAMAR, (D) Sajida PARVEEN University of the Punjab, Punjab University College of Pharmacy, Lahore, Pakistan

\begin{abstract}
Objectives: The present study aimed to enhance the aqueous solubility of methanol extract of leaves of Vinca rosea (family: Apocynaceae) by particle-size reduction using milling and to evaluate its antidiabetic activity.

Materials and Methods: The methanol extract (ME) was micronized using a vibratory ball mill, operated at a vibratory speed of $15 \mathrm{~Hz}$ for 60 min at room temperature, and the resulting extract micronized ME (MME) was investigated to determine particle size, solubility, UV/visible profile, and in vitro antidiabetic activity.

Results: The average particle size of MME was $0.753 \pm 0.227 \mu \mathrm{m}$, which was less than half of that of the ME $(2.007 \pm 0.965 \mu \mathrm{m})$. The solubility of MME was greater than that of the ME. MME exhibited $65.63 \%, 18.0 \%$, and $96.87 \%$ higher antidiabetic activity in the glucose uptake by the yeast cells method, hemoglobin glycosylation assay, and the alpha amylase inhibition assay, respectively ( $p<0.05$ ).

Conclusion: The results of the present study indicate that micronization effectively enhanced the aqueous solubility and antidiabetic activity of methanol extract of leaves of Vinca rosea.
\end{abstract}

Key words: Vinca rosea, methanol extract, micronization, solubility, antidiabetic activity

öz

Amaç: Bu çalışmada Vinca rosea (familya: Apocynaceae) yapraklarının metanol ekstresinin öğütme işlemi kullanılarak partikül büyüklüğünün azaltılması ile sudaki çözünürlüğünün artırılması ve antidiyabetik aktivitesinin değerlendirilmesi amaçlanmıștır.

Gereç ve Yöntemler: Metanol ekstresi (ME) titreșimli bir bilyalı değirmen kullanılarak oda sıcaklığında 60 dakika boyunca 15 Hz'lik bir titreşim hızında mikronize ME (MME) edilmiş ve elde edilen ekstrenin partikül büyüklüğü, çözünürlüğü, UV/görünür bölge profili ve in vitro antidiyabetik aktivitesi araştırılmıştır.

Bulgular: MME'nin ortalama partikül büyüklüğünün $0.753 \pm 0.227 \mu$ m olduğu ve bu değerin ME'nin partikül büyüklüğünün $(2.007 \pm 0.965 \mu m)$ yarısından az olduğu belirlenmiştir. MME'nin çözünürlüğünün, ME'ninkinden daha fazla olduğu saptanmıştır. MME, glukoz alımında, maya hücreleri yöntemi, hemoglobin glikozilasyon ve alfa amilaz inhibisyon deneylerinde, sırasıyla \%65.63, \%18.0 ve \%96.87 daha yüksek antidiyabetik aktivite sergilemiștir (p<0.05).

Sonuç: Bu çalıșmanın sonuçları, mikronizasyonun, Vinca rosea yapraklarının metanol ekstresinin suda çözünürlüğünü ve antidiyabetik aktivitesini etkili bir şekilde artırdığını göstermektedir.

Anahtar kelimeler: Vinca rosea, metanol ekstresi, mikronizasyon, çözünürlük, antidiyabetik aktivite

*Correspondence: E-mail: hussain_761@yahoo.com, Phone: +92 3324249323 ORCID: orcid.org/0000-0001-9627-8346

Received: 01.04.2018, Accepted: 03.07.2018

-Turk J Pharm Sci, Published by Galenos Publishing House. 


\section{INTRODUCTION}

The surge in interest among the public towards plant-based drugs is increasing day by day. However, mostly such products show poor aqueous solubility and oral bioavailability, leading to challenges in formulation development and efficacy. As a result, active constituents cannot reach the target site at a rate and extent needed to elicit therapeutic response. Several techniques may be used to improve aqueous solubility and oral bioavailability. Among such techniques, particle-size reduction (micronization) is one of the oldest approaches to improving solubility. Micronization, a conventional technique for size reduction, is commonly used for enhancing solubility. This technique reduces particle size up to 2-5 $\mu \mathrm{m}$ usually, but sometimes below $1 \mu \mathrm{m}^{2}$ For such purpose, jet milling, ball milling, and high-pressure homogenization machines are used frequently.' In the present study, a ball mill was used to reduce the particle size of extract of leaves of a traditional medicinal plant, Vinca rosea.

The plant is well known due to its alkaloids such as vincristine and vinblastine for treating cancer. ${ }^{3}$ As a folkloric medicine, fresh leaves of the plant are chewed to manage diabetes. The scientific evidence for this use was reported due to isolation of alkaloids such as vindoline, vindolidine, vindolicine, and vindolinine, which had antidiabetic activity. ${ }^{4}$ The three alkaloids exhibited quite high median inhibitory concentration for cell viability and hence are considered safe to consume. Moreover, such alkaloids are poorly soluble in aqueous medium and suspected to have a low systemic level so that they exhibit cytotoxicity. The extracts of the plant contain flavonoids and polyphenols that have antidiabetic activity as well..$^{5}$ The activity of extract of the plant may be enhanced by increasing aqueous solubility by micronization. Therefore, the present study aimed to reduce the particle size of methanol extract (ME) of leaves of $V$. rosea and evaluate the antidiabetic activity of micronized ME (MME). The results of the present study may enhance the utilization of this plant for managing diabetes.

\section{MATERIALS AND METHODS}

\section{Collection and extraction}

The plant was acquired from the National Agricultural Research Centre, Islamabad, Pakistan. The leaves were separated, washed, dried under shade, and pulverized. Powdered material $(75 \mathrm{~g})$ was macerated with $200 \mathrm{~mL}$ of methanol for 5 days. The solvent was removed and the extraction was repeated three times using the same volume of methanol. The extract was filtered and dried in vacuo at $40^{\circ} \mathrm{C}$, and termed ME.

\section{Micronization of extract}

A vibratory ball mill (locally manufactured, Lahore, Pakistan) was used in this study. It was fitted with two stainless steel cylinders $(10 \mathrm{~cm}$ in length, $32 \mathrm{~mm}$ in internal diameter) each containing one stainless steel ball ( $25 \mathrm{~mm}$ in diameter). A total of $3 \mathrm{~g}$ of ME was added to each of the cylinders, fitted in the mill, and micronized by operating the machine at a vibratory speed of $15 \mathrm{~Hz}$ for $60 \mathrm{~min}$ at room temperature. The resulting extract was termed MME.

\section{Chemicals}

Metronidazole (Siza International, Lahore, Pakistan), alpha amylase and hemoglobin (China), acarbose (Bayer, Pakistan), methanol (RCI Labscan, Thailand), glucose, starch, gallic acid, and enthrone reagent (Sigma Aldrich) were procured from the local market.

\section{Characterization of ME and MME}

ME and MME were subjected to scanning electron microscopy (SEM) to determine the particle morphology in the magnification range from lower to higher (1.00 kx and $25.0 \mathrm{kx}$ ). The various sized particles were observed in the magnification range of $10.0 \mathrm{kx}$ and average particle size was determined by Image J (software). Both the extracts were dissolved in methanol to obtain solutions having a final concentration of $1.0 \mathrm{mg} / \mathrm{mL}$. These solutions were scanned in the UV/visible range (800$200 \mathrm{~nm}$ ) and the spectra were compared with each other. The aqueous solubility of ME and MME was assessed by taking 10 $\mathrm{mg}$ of extract in separate test tubes containing $10 \mathrm{~mL}$ of water. The samples were allowed to dissolve by shaking by hand and if not soluble were subjected to sonication for $1 \mathrm{~min}$. The formation of a clear homogeneous solution indicated solubility.

\section{Antidiabetic activity}

\section{Glucose uptake by yeast cells}

The method described by Kumar et al. ${ }^{6}$ was used to study glucose uptake by yeast cells. Briefly, the yeast cells were rinsed with distilled water by centrifugation at $2500 \mathrm{rpm}$ for $5 \mathrm{~min}$ and the procedure was repeated until the supernatant became clear. Then a yeast cell pellet was suspended in water to prepare $10 \%$ suspension ( $\mathrm{v} / \mathrm{v})$. One milliliter of $10 \mathrm{mM}$ glucose solution and $1 \mathrm{~mL}$ of each extract/standard (metronidazole) were mixed and incubated at $37^{\circ} \mathrm{C}$ for $10 \mathrm{~min}$. Then $100 \mu \mathrm{L}$ of yeast suspension was added and mixed and incubation was continued for $1 \mathrm{~h}$ at $37^{\circ} \mathrm{C}$. Afterwards, the mixture was centrifuged at $2500 \mathrm{rpm}$ for $5 \mathrm{~min}$ and the supernatant was used to determine the glucose concentration. The percentage glucose uptake was computed using the following formula:

Percentage uptake $=\frac{[\text { Absorbance of control-Absorbance of sample] }}{\text { Absorbance of control }}$

\section{Hemoglobin glycosylation inhibition activity}

The activity was determined using the procedure described by Parker et al. ${ }^{7}$ Briefly, $1 \mathrm{~mL}$ of hemoglobin $(0.06 \%, w / v)$, gentamycin $(0.02 \%, \mathrm{w} / \mathrm{v})$, sample/standard (gallic acid) solution, and glucose $(2 \%, \mathrm{w} / \mathrm{v})$ were mixed and incubated in the dark at room temperature for $72 \mathrm{~h}$. Then the absorbance was measured at $440 \mathrm{~nm}$ and the percentage inhibition of hemoglobin glycosylation was determined using the formula given as follows:

Percentage activity $=\frac{[\text { Absorbance of control-Absorbance of sample }]}{\text { Absorbance of control }}$ 


\section{Alpha amylase inhibition activity}

The activity was determined using the method developed by Ramakrishna et al. ${ }^{8}$ Briefly, $1 \mathrm{~mL}$ of enzyme solution $(0.5 \mathrm{mg} /$ $\mathrm{mL}$, in $20 \mathrm{mM}$ phosphate buffer of $\mathrm{pH} 6.9$ ) and $1 \mathrm{~mL}$ of extract/ standard (acarbose) solution were mixed and incubated at $37^{\circ} \mathrm{C}$ for $10 \mathrm{~min}$. Then $1 \mathrm{~mL}$ of $1 \%$ starch solution was added and the reaction mixture was again incubated at $37^{\circ} \mathrm{C}$ for $10 \mathrm{~min}$. Finally, the reaction was stopped by adding $2 \mathrm{~mL}$ of dinitrosalicylic acid and the mixture was further heated in a boiling water bath for $8 \mathrm{~min}$. The contents were cooled and the absorbance was measured at $540 \mathrm{~nm}$. The \% inhibition of the enzyme activity was calculated by the formula given as follows:

Percentage activity $=\frac{\text { [Absorbance of control-Absorbance of sample] }}{\text { Absorbance of control }}$

\section{Statistical analysis}

The data were analyzed by one-way ANOVA with Bonferroni post hoc multiple comparison. A p value $<0.05$ was considered significantly different.

\section{RESULTS AND DISCUSSION}

\section{Micronization and characterization of extracts}

The MME and ME of leaves of $V$. rosea were compared with each other in terms of morphology, size distribution, solubility, UV/visible absorbance behavior, and antidiabetic activity. The morphology of ME and MME, determined by SEM at lower and higher magnification (1.0 kx and $25.0 \mathrm{kx}$ ), is shown in Figures 1 and 2 , respectively. The particle-size distribution, determined in the magnification range of $10.0 \mathrm{kx}$, of ME and MME is given in Figure 3. The particles of ME appeared angular with low sphericity, whereas the particles of MME appeared rounded with medium sphericity. The spherical smaller particles
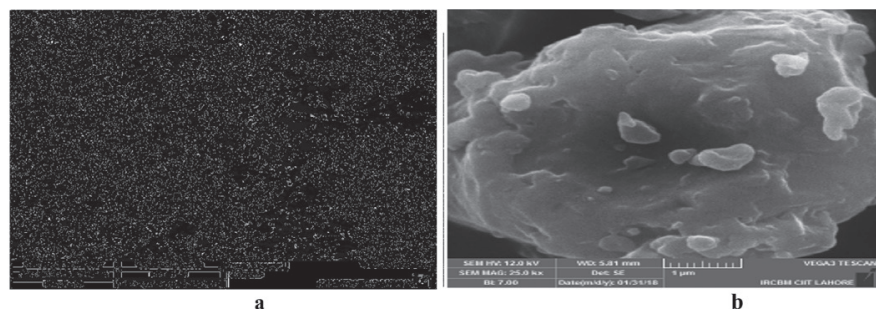

Figure 1. Scanning electron microscopy images of methanol extract of leaves of Vinca rosea at lower (a) and higher magnification (b)

SEM: Scanning electron microscopy
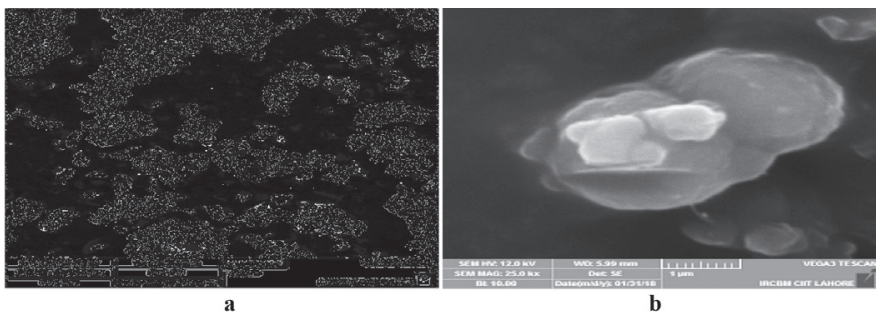

Figure 2. Scanning electron microscopy images of micronized methanol extract of leaves of Vinca rosea at lower (a) and higher magnification (b) showed agglomeration due to the micronization process. These results show that micronization enhanced flowability, packing, and interaction with fluids and the covering power of pigments, which are much needed properties of a pharmaceutical material.

The average particle size of ME prior to micronization, determined from SEM data by applying ImageJ, was $2.007 \pm 0.0965 \mu \mathrm{m}$, whereas the average particle size of MME was $0.753 \pm 0.227 \mu \mathrm{m}(62.48 \%$ reduction in size). Hence, the milling had increased the surface area of the particles.

The impact of micronization on the aqueous solubility of the extract was positive. The solubility of ME in distilled water was $2 \mathrm{mg} / \mathrm{mL}$ with sonication, whereas MME was soluble in water in the same proportion without sonication. This ease of solubility was due to smaller particle size as described by the NoyesWhitney equation, which indicated that when particles became smaller the surface area to volume ratio was increased. The larger surface area allowed greater interaction with the solvent molecules, which resulted in increased solubility. The reduction in the particle size increases the rate of solution because of the large surface area. ${ }^{9}$

The overlays of the UV/visible spectra of ME and MME of leaves of $V$. rosea are shown in Figure 4 . The spectra of both the extracts were superimposable, indicating chemical similarity of the extracts. These results clearly indicated that milling had not affected the chemical nature of the constituents of the extract. Thus, the solubility was increased due to milling but without any chemical change.

The improvement in the solubility of MME of leaves of $V$. rosea is of great importance. The plant is reported to contain antidiabetic alkaloids and polyphenols/flavonoids that are either insoluble or poorly soluble in water. In the present study, plant material was defatted with petroleum ether and then its alkaloidal contents were further reduced by extracting the residue with chloroform, in which alkaloids were soluble. The residue was extracted with methanol so that the extract contained polar compounds such as polyphenols and flavonoids in higher proportions. This extract was subjected to milling to enhance the aqueous solubility of MME and its chemical constituents, leading to higher efficacy. To confirm this fact, both types of extracts were investigated for antidiabetic activity, the traditional use of the plant, using different in vitro models.

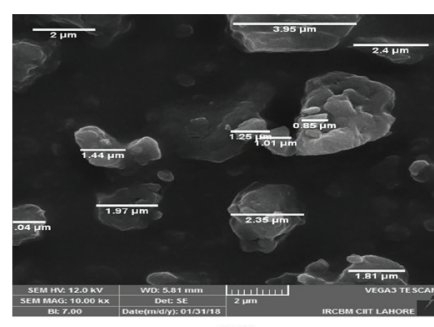

$\mathrm{ME}$

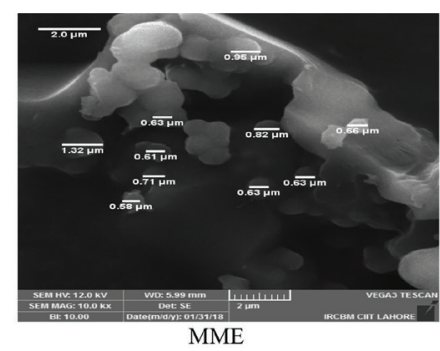

MME
Figure 3. Scanning electron microscopy images of methanol and micronized methanol extracts showing particles of various sizes in the magnification range of $10.0 \mathrm{kx}$

ME: Methanol extract, MME: Micronized methanol extract 


\section{Antidiabetic activity}

The effect of micronization on the antidiabetic activity of ME and MME of leaves of the plant using three in vitro models is shown in Figure 5. In all three models, MME showed higher activity as compared to ME and standard drug $(p<0.05)$. The activity of MME was $63 \%$ higher in glucose uptake by the yeast cell assay, $18.0 \%$ higher in inhibition in the hemoglobinglycosylation inhibition assay, and $96.87 \%$ higher in the alpha amylase inhibition assay than that of ME. These results explicitly indicate the positive effect of physical modification of particle size on hypoglycemic activity.

In the present study, MME showed higher uptake of glucose in yeast cells as compared to ME. This increase in activity is due to the reduction in particle size and higher aqueous solubility. Owing to such behavior the constituents of the extract can enter yeast cells at a higher rate and extent, thereby facilitating glucose utilization within the cell. This creates a concentration gradient

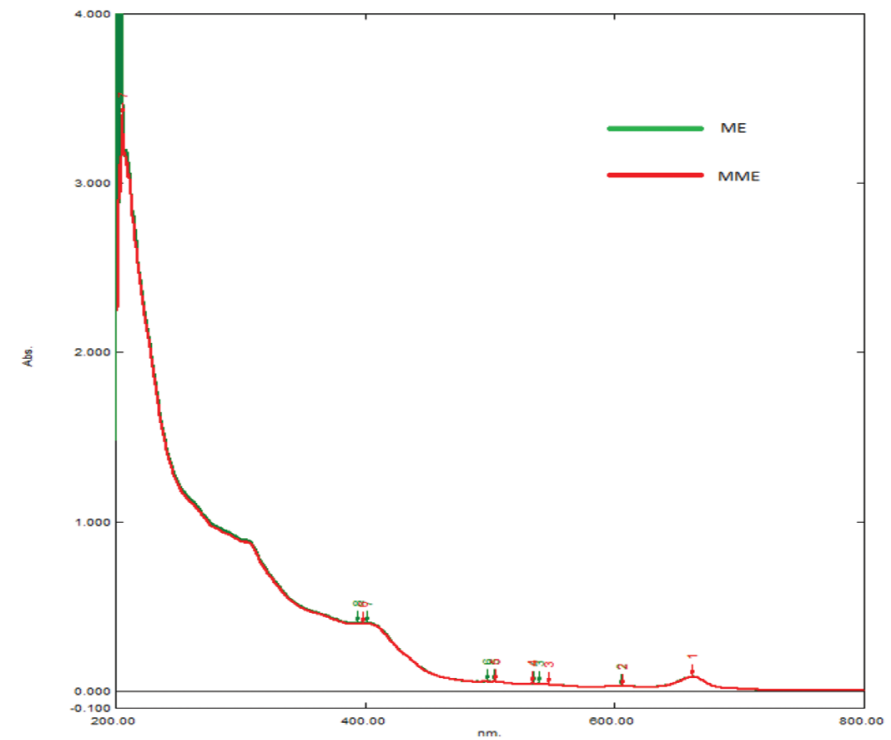

Figure 4. Overlays of UV/visible profiles of methanol extract and micronized methanol extract of leaves of Vinca rosea

UV: Ultraviolet

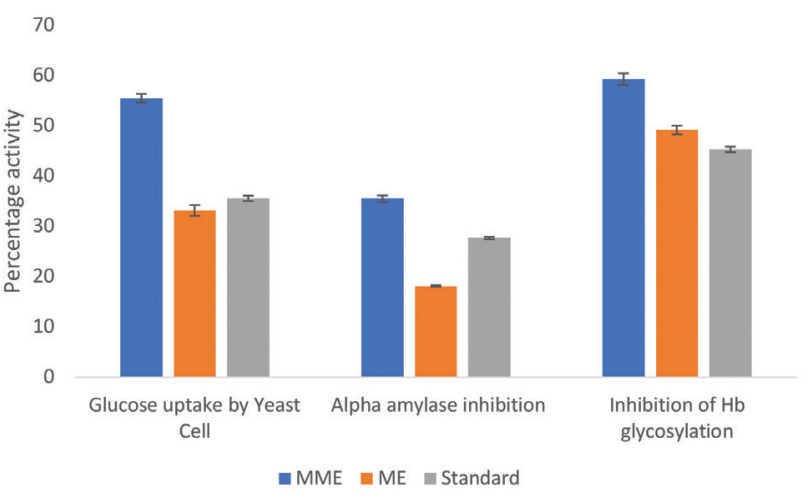

Figure 5. Antidiabetic activity of MME, ME, and standard using glucose uptake by yeast cells, hemoglobin glycosylation, and alpha amylase inhibition assay across the membrane and facilitates the movement of glucose from the solution to the cell. It is reported that glucose uptake in yeast cells takes place through facilitated diffusion catalyzed by glucose transporter and hence the compounds enhancing the activity of the transporter can increase glucose uptake. ${ }^{10}$ As the glucose enters the yeast cell, phosphorylation takes place, which prevents the glucose molecules from diffusing back and creating a concentration gradient. ${ }^{10}$ Therefore, MME entered the cells much faster than ME and enhanced the transport of glucose from the solution to the cells due to facilitated diffusion and phosphorylation.

Likewise, the inhibition of $\mathrm{Hb}$ glycosylation with MME is higher as compared to ME. The glycosylation can be inhibited in two ways: blocking the glucose so that it cannot interact with the amino group of the beta chain of hemoglobin, and blocking the amino group of the hemoglobin. The activity of the extract may be multifaceted because it contains alkaloids, soluble proteins, polyphenols, and flavonoids. The nitrogen groups of the alkaloids and soluble proteins may block the aldehyde group of glucose, thus reducing its availability to react with hemoglobin. The polyphenols and flavonoids can act as proton donors to reduce the aldehyde group of the glucose. The same is reported about the glycosylation inhibition activity of polyphenols and flavonoids. 11,12 The extract might have shown all such effects in glycosylation inhibition.

$\mathrm{Hb}$ glycosylation has attained much importance in the modern world due to its use as a scale in the long-term control of diabetes. Glycosylation is a nonenzymatic process of attaching glucose molecules with the amino group of $\mathrm{Hb}$, leading to the formation of advanced glycated end products. Antioxidants prevent this oxidation process and so in a way inhibit $\mathrm{Hb}$ glycosylation. ${ }^{12}$

The inhibitory response of MME against alpha amylase, an important therapeutic target of diabetic control, was also superior to that of ME. This enzyme hydrolyzes the alpha glycosidic bond and converts starch into glucose. The phenolic compounds of the extract can show alpha amylase inhibition action as reported earlier. ${ }^{13}$ The inhibitory potential of these metabolites is related to the presence of a hydroxyl group that forms hydrogen bonding between the hydroxyl group and catalytic residue of the binding site of enzyme. ${ }^{13}$ The difference in activity between ME and MME was due to the micronization process. The extracts due to differential solubility interacted with the enzyme differently. The micronization process converted the extract into amorphous particles, which resulted in improved solubility. The amorphous form is more readily soluble because of higher Gibbs free energy. ${ }^{14}$ The abovementioned results indicated that smaller particles with larger surface area might have an improved antidiabetic effect.

Traditional micronization has some limitations such as morphology and particle properties that are uncontrolled as compared to novel size reduction techniques. Heterogeneous particle shape and agglomeration are observed in the ball milling method, which can be prevented by particle engineering techniques. Micronization using other methods such as jet 
milling and high pressure homogenization can be used to observe the difference between the results.

\section{Study limitations}

Traditional micronization has some limitations such as morphology and particles properties that are uncontrolled as compared to novel size reduction techniques. Heterogeneous particle shape and agglomeration are observed in the ball milling method, which can be prevented by particle engineering techniques. Most of the new chemical entities in drug research are poorly water soluble. Therefore, attempts should be made to enhance water solubility by micronization, which would in turn increase the pharmacological activity.

\section{CONCLUSIONS}

The results of the present study show that micronization increases the solubility and antidiabetic activity of methanol extract of leaves of $V$. rosea without causing any chemical change.

\section{ACKNOWLEDGEMENTS}

We are grateful to COMSATS, Lahore Campus, Pakistan, for the SEM studies.

Conflict of Interest: No conflict of interest was declared by the authors.

\section{REFERENCES}

1. Khadka P, Ro J, Kim H, Kim I, Kim JT, Kim H, Cho JM, Yun G, Lee J. Pharmaceutical particle technologies: An approach to improve drug solubility, dissolution and bioavailability. Asian J Pharm Sci. 2014;9:304316.

2. Rawat N, Kumar MS, Mahadevan N. Solubility: Particle size reduction is a promising approach to improve the bioavailability of lipophillic drugs. Int J Adv Pharm Res. 2012;1:8-18.
3. Farnsworth NR, Bingel AS. Problems and prospects of discovery new drugs from higher plants by pharmacological screening. Springer Verlag, Berlin. 1977;1-22.

4. Tiong SH, Looi CY, Hazni H, Arya A, Paydar HJ, Wong WF, Cheah SC, Mustafa MR, Awang K. Antidiabetic and antioxidant properties of alkaloids from Catharanthus roseus (L.) G. Don. Molecules. 2013;18:97709784.

5. Umeno A, Horie M, Murotomi K, Nakajima Y, Yoshida Y. Antioxidative and antidiabetic effects of natural polyphenols and isoflavones. Molecules. 2016;21:708.

6. Kumar B, Dinesh A, Mitra M. In vitro and in vivo studies of antidiabetic Indian medicinal plants. A review. J Herb Med Tox. 2009;3:9-14.

7. Parker KL, England JD, Da Costa J, Hess RL, Goldstein DE. Improved colorimetric essay for glycosylated haemoglobin. Clin Chem. 1981;25:669672.

8. Ramakrishna SV, Suseela T, Ghilyan NP, Jalil A, Prema P, Lonsane BK, Ahmed SY. Recovery of amyloglucosidase from moulay bran. Indian J Technol. 1982;20:476-480.

9. Chaudhary A, Nagaich U, Gulati N, Sharma VK, Khosa RL. Enhancement of solubilization and bioavailability of poorly soluble drugs by physical and chemical modifications: A recent review. J Adv Pharm Edu Res. 2012;2:32-67.

10. Weusthuis RA, Pronk JT, Broek PJA, Dijken JPV. Chemostat cultivation as a tool for studies on sugar transport in yeasts. Microbiol Rev. 1994;616-630.

11. Yeh WJ, Hsia SM, Lee WH, Wu CH. Polyphenols with antiglycation activity and mechanisms of action: a review of recent findings. J Food Drug. 2017;25:84-92.

12. Sadowska BI, Galiniak SBG. Kinetics of glycoxidation of bovine serum albumin by glucose, fructose and ribose and its prevention by food components. Molecules. 2014;19:18828-18849.

13. Sales PMD, Souza PMD, Simeoni LA, Magalhaes PDO, Silveira D. $\alpha$-amylase inhibitors. A review of raw material and isolated compounds from plant source. J Pharm Pharmaceut Sci. 2012;15:141-183.

14. Graeser KA, Patterson JE, Zeitler JA. The role of configurational entropy in amorphous systems. Pharmaceutics. 2010;2:224-244. 